\title{
Evaluation of anti anemic prospective of natural iron sources in lactating women- an ignored important segment of Pakistani population
}

\author{
Muhammad ABDULLAH ${ }^{1}$ (D), Shahid MAHMOOD ${ }^{2}$, Zaheer AHMED ${ }^{1 *}$
}

\begin{abstract}
Almost entire segment of expecting and breastfeeding mothers in Pakistan are severely affected by iron deficiency anemia (IDA) with predictable prevalence of $50 \%$ and as severe public health problem in lactating mothers, has worldwide pervasiveness. Commonly used synthetic iron sources provoke complications. Thus, food sources are preferred due to high bioavailability and sustainability. The present study was done on various natural and synthetic iron sources evaluated for proximate composition, mineral matter, sensory attributes and storage stability. The treatments were fed for 90 days and their efficacy was tested among anemic lactating women. The blood samples of 862 women were taken to examine their hemoglobin level and pertinent biomarkers. Hence, $37.00 \%$ volunteers were found to be anemic $(\mathrm{Hb}<11 \mathrm{~g} / \mathrm{dL})$ and $67.71 \%$ women showed IDA problem. Finally, 200 volunteers were strewn arbitrarily into 4 groups. All treatments provided 50\% RDA of iron. Dietary intakes and biochemical investigations of $\mathrm{T}_{2}$ group showed momentous improvement $(P<0.05)$ while linear variations were recorded in anthropometrics, liver function tests (LFTs) and renal function tests (RFTs). Study revealed that food iron sources are easily accessible, cheaper, safe and has more bioavailable iron in skirmishing IDA among lactating women on sustained basis.
\end{abstract}

Keywords: food iron; synthetic source; lactating women; IDA.

Practical Applications: The investigated natural iron sources i.e. molasses and dried fruit may be effectively used in the food processing industry for the production of fortified food products so as to address or minimize or prevent nutrient deficiencies in the deficient population.

\section{Introduction}

Anemia is a condition in which blood hemoglobin level is reduced from normal concentration $(\mathrm{Hb}<11 \mathrm{~g} / \mathrm{dL}$ in lactating women) and it hinders the supply of oxygen to blood which badly distress mother and child health, newborn development, working competence, astuteness and earning power of employment span (Sathyamala, 2017). These effects among community lead to significant economic setback due to inevitable GDP and disease management expenses. Anemia affects one third of adult population and more than 2 billion inhabitants on the globe. Predominantly it occurs among females of childbearing age because menstrual cycle, pregnancy, child birth and lactation increase iron requirements of body (Kassebaum et al., 2010). Unsurprisingly, entire segment of expecting and breastfeeding mothers in Pakistan are seriously affected by IDA and probable incidence of this malady among women of childbearing age is fifty percent. Due to this reason, maternal and child mortality rate is high in Pakistan. Anemia prevalence among Indian lactating mothers is reported to be $63 \%$ (Siddiqui et al., 2017). When prevalence of anemia is $\geq 40 \%$, public health problem is severe in nature (Mhanna et al., 2016). Symptoms of IDA are lassitude, tiredness, ringing in ears, paleness, reduced immunity, impaired growth, watery conjunctivae, taste disorder, spoon nails, ice craving and glossitis. Decrease in $\mathrm{Hb}$ concentration during pregnancy is about $10 \%$. Postpartum blood volume decreases according to blood loss during child birth and, $\mathrm{Hb}$ levels also decreases straight away after the delivery due to fluids reorganization. Iron is necessary for some fundamental body functions such as oxygen transportation to cells and $\mathrm{Hb}$ regeneration by erythropoietin mechanism. Synthesis of $\mathrm{Hb}$ and red blood cells will not occur if iron supply is inadequate (Milman, 2011).

Iron binds to carrier transferrin which uptakes iron through receptors. Excessive iron unable to attach with receptors is labile cellular iron that may abandon in red blood cells particularly blood administration during chronic anemia (Wessling-Resnick, 2017). Iron deposited in excess may not absorb efficiently in the gastrointestinal tract (GIT). Various indispensable nutrients of food origin that influence iron absorption (Cepeda-Lopez et al., 2015) are termed as dietary inhibitors (polyphenols and tannins) and enhancers (vitamin $\mathrm{C}$ and $\alpha$-tocopherols). Blackstrap molasses is a treasure of minerals that gives more iron than red meat, builds iron stores, contains fewer calories and its two tablespoonfuls provide $13.3 \% \mathrm{RDA}$ of iron. It is very useful during menstruation, breastfeeding, pregnancy and also for growing children (Jain \& Venkatasubramanian, 2017). Dates are rich source of minerals which express their vital role in hemoglobin and bone make up (Saryono \& Rahmawati, 2016). Apricot is a rich source of iron, potassium, beta-carotene and is useful for 
bone, teeth and Hb synthesis (Yilmaz et al., 2012). Blackstrap molasses, dates and apricot contain 25, 0.58 and $40 \mathrm{mg} / 100 \mathrm{~g}$ bioavailable iron, respectively. Rape seed is also a rich source of iron $(10 \mathrm{mg} / 100 \mathrm{~g})$ while $3.07 \mathrm{mg}$ elemental ferrous sulphate powder contains $1 \mathrm{mg}$ iron (US Department of Agriculture, 2018). In Pakistan, 2 million tons molasses is produced every year which is the main by-product of sugarcane industry and its recovery is about $5 \%$ of the sugarcane plant. The current study focused the important ignored segment of lactating women in Pakistan while considering cheap, easily available, abundant and waste material of sugar industry such as blackstrap molasses (already being used as animal feed in the country). Therefore, the prime objective of the study was to investigate the nutritional profile of various natural iron sources. Moreover, impact of natural iron sources and Ferrous Sulphate on IDA in lactating mothers was compared and correlation between dietary intakes and IDA was also established.

\section{Materials and methods}

Four treatments of food and synthetic sources of iron were formulated (Table 1) and qualitatively analyzed for proximates, mineral composition, calorific content and sensory attributes fortnightly for 60 days and their impact was evaluated after 90 days among lactating women who were screened to be IDA patient.

\subsection{Efficacy studies of iron treatments}

This study was conducted according to the guidelines laid down in the Declaration of Helsinki and all procedures involving human subjects/patients were approved by the Departmental Review Committee for Ethics (DRCE), Institute of Home and Food Sciences (IHFS), GC University, Faisalabad vide letter no. GCUF/IHFS/12-001 dated 22-01-2016. The study was also approved and registered in the BASAR committee meeting of Allama Iqbal Open University (AIOU), Islamabad held on 04-02-2016 under the chairmanship of Vice Chancellor of AIOU vide letter no. AIOU-VC/HHS/30-55 dated 04-02-2016 (Zoccatelli et al., 2018).

The lactating females (15-49 years) with $\mathrm{Hb}<11.0 \mathrm{~g} / \mathrm{dL}$ (Sathyamala, 2017), serum ferritin (s. Ferritin) $<12 \mathrm{ug} / \mathrm{L}$ (Milman, 2011), serum iron (s. Fe) $<60 \mathrm{ug} / \mathrm{dL}$, total iron binding capacity (TIBC) $>350 \mathrm{mg} / \mathrm{dL}$, transferrin saturation (TS) $<15 \%$ (Manavifar et al., 2014) and mean corpuscular volume $(\mathrm{MCV})<80 \mathrm{fL}$ (Anand et al., 2018) were selected as participant of the study while women having liver and kidney problems, hemorrhoids and/ or acute menstrual bleed were disqualified for the study. The selected volunteers were dewormed by Praziquantel administered as $40 \mathrm{mg}$ per kg body weight (Inobaya et al., 2018) followed by a fortnight booster dose. Prior written consent of the female to be a participant for the current research study was taken. Study site selected after approval of concerned authority consisted of 20 Population Welfare Centers (PWCs), Faisalabad, Government of Punjab-Pakistan. The selection of human subjects was carried out in accordance to two stage sampling. Adopting the above method, the required sample size was 2585 women (Nath, 2015). By considering economy and convenience, $862\left(1 / 3^{\text {rd }}\right.$ of required sample size) lactating women randomly selected and screened for $\mathrm{Hb}$ level through B-Hemoglobin Photometer (Model: K061047 HEMOCUE AB, Angelholm, Sweden); 37.00\% women were found to be anemic $(\mathrm{Hb}<11 \mathrm{~g} / \mathrm{dL})$. At last, 200 volunteers were allocated randomly into 4 treatment groups of 50 volunteers each (Figure 1). Their blood was collected in two pre-coded tubes, wrapped in Aluminum foil, kept in an ice box and shifted to Food and Nutrition Lab. for further analysis.

The blood of tube-I was analyzed for ABO blood grouping and CBC like red blood cells (RBC), Hb, hematocrit (Hct), Mean Corpuscular Hemoglobin (MCH), Mean Corpuscular Hemoglobin Concentration (MCHC) and MCV that were analyzed through fully Automatic Blood Analyzer, Nihon Kohden, Japan. Serum was extracted from blood of tube-II by centrifuge machine (Model: 800, Centrifugal Machine, China). Serum Fe and TIBC were estimated by Colorimetric method through Microlab-300, Merck Germany while s. Ferritin was analyzed by Immunoassay technique through Access 2 (Model: 510-K, Beckman Coulter, Inc. USA) and TS was determined by the standard formula. The study design for research project was randomized controlled clinical trial (Spieth et al., 2016). Anthropometric measurements, hematological and biochemical investigations were the research instruments for said project (Sharami et al., 2017). Demographics such as volunteers' family income etc. and anthropometrics of the selected subjects were recorded (Anand et al., 2018). Food frequency questionnaire (FFQ) and Food Diary were used to assess dietary intakes at baseline and during the intervention. Clinical signs and symptoms and vital signs such as body temperature $\left({ }^{\circ} \mathrm{F}\right)$, blood pressure $(\mathrm{mmHg})$ and pulse rate (beats/minute) of all the selected volunteers were also recorded throughout the study (Herranz-Lopez et al., 2019). Lactating volunteers were randomly allocated in to $\mathrm{T}_{0}, \mathrm{~T}_{1}, \mathrm{~T}_{2}$ and $\mathrm{T}_{3}$ groups. Each volunteer was daily fed one capsule / sachet of allocated treatment so as to congregate their 50\% RDA (4.5 mg) of Fe. Every volunteer visited PWC once a week and collected a packet of her individual treatment containing 7 doses and brought back Food Diary and empty packets. At the end of study, all volunteers paid a visit to PWCs for the assessment of anthropometrics, energetic and vital signs recording. Blood samples were recollected and analyzed as described earlier in detail.

Table 1. Detail of various treatments of iron.

\begin{tabular}{cllc}
\hline Treatments & \multicolumn{1}{c}{ Composition } & \multicolumn{1}{c}{ Dose } & \multicolumn{1}{c}{ Fe Content (mg) } \\
\hline $\mathrm{T}_{0}$ & 250 mg Lactose as filler in capsule (control) & 1 Capsule & 00.0 \\
$\mathrm{~T}_{1}$ & 23.63 g Blackstrap molasses (viscous liquid; net wt: $24 \mathrm{~g}$ in sachets) & 1 Sachet & 04.5 \\
$\mathrm{~T}_{2}$ & 17.10 g Blackstrap molasses + 3.0 g dried Dates + 3.0 g dried Apricots + 3.0 g & 1 Sachet & 04.5 \\
& Rape seeds (semi solid paste; net wt: $26.50 \mathrm{~g}$ in sachets) & & 1 Capsule \\
$\mathrm{T}_{3}$ & 13.84 mg Ferrous sulphate + 236.16 mg Lactose in capsule & & 04.5 \\
\hline
\end{tabular}




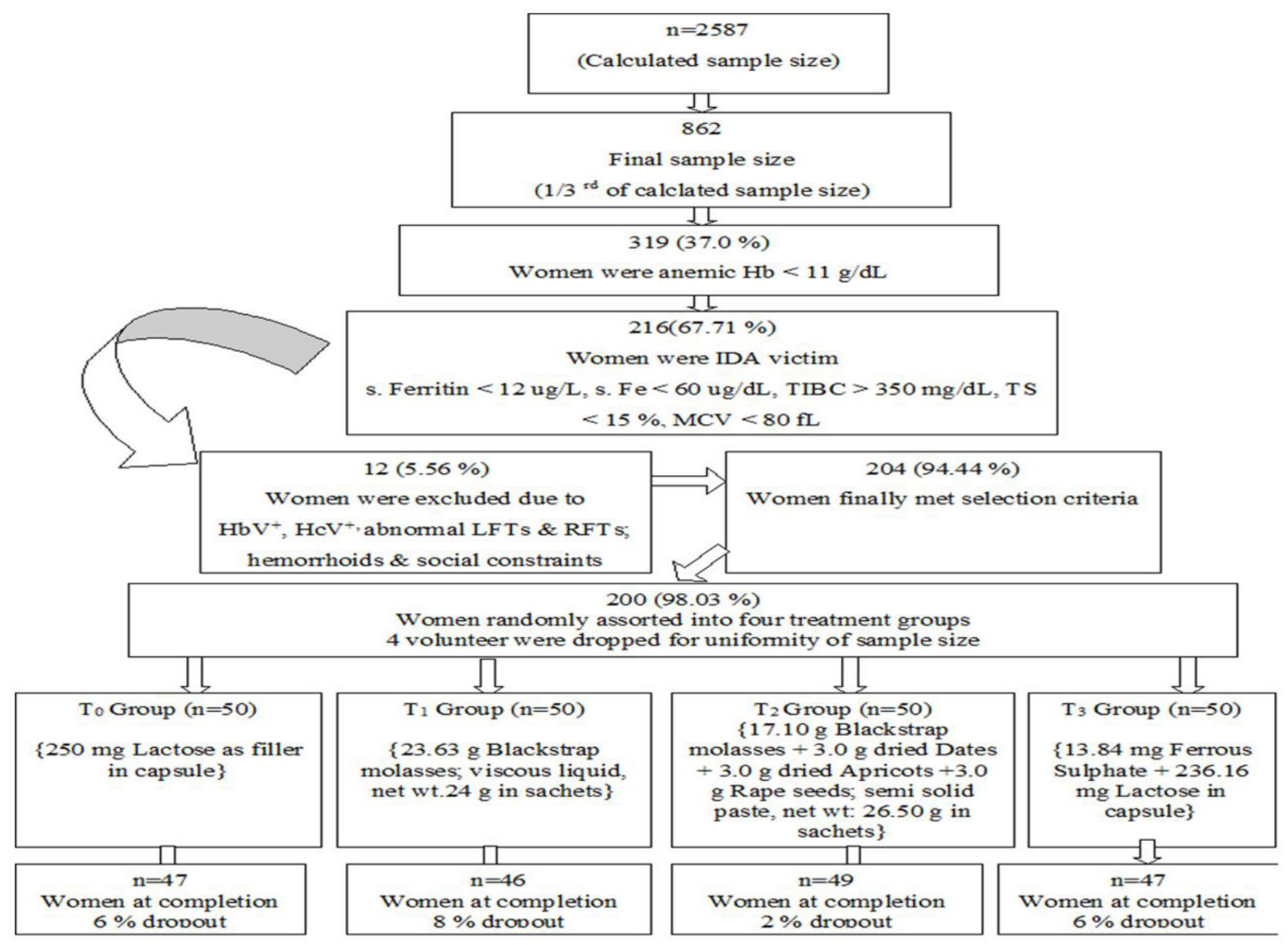

Figure 1. Flow diagram of lactating volunteer' screening and assortment.

\subsection{Statistical analysis}

Data collected during interventional study was analyzed with the help of statistical software SPSS-20. Data distribution and frequency was examined by applying the descriptive statistics. One way analysis of variance (ANOVA) technique was utilized to further analyze the collected data set and significance ( $\mathrm{p} \leq 5 \%)$ between groups was established through LSD test. Paired t-test was used to find out the correlation between variables. The results of the statistical analysis so obtained for various treatments of iron intervention were interpreted on logical grounds and consequently conclusions were drawn.

\section{Results and discussion}

\subsection{Demographics of volunteers}

Demographic variable of mean age (years) and married years of the lactating women were 29.37 and 7.93 , respectively. Number of children and family members (no.) were found to be 2.82 and 8.54 , respectively. History of abortion, miscarriage and premature births was $2.17,0$ and $2.17 \%$, respectively. Joint family system was $96.20 \%$ and nuclear family system was found in $3.80 \%$ subjects. In this group, 70.11, 16.85 and $13.04 \%$ mothers reported breastfeeding, breastfeeding plus bottle feeding and no breastfeeding (bottle feeding), respectively. Regarding lactation period; $42.39,9.78$ and $9.24 \%$ mothers explained $<1$ year breastfeeding, breastfeeding plus bottle feeding and no breastfeeding (bottle feeding), respectively. Majority of the mothers $(90.22 \%)$ had sedentary level of physical activity while family income was less than Rs. 39000/- in 7.61\% and less than Rs.20000/- among 92.39\% women (Table 2). In a study of 327 Ethiopian lactating females (Egata, 2018), demographic data and anemia associated risk factors were collected on the predesigned questionnaires. Majority of illiterate mothers with poor socioeconomic status, multiple gravida and low dietary diversity score (intake from less food groups than standard) from the age group 25-34 years were anemic (28.7\%) and history of abortion was acknowledged in $9 \%$ of these volunteers. Low diet diversity score leads to inadequacy of vitamins and minerals along with compromised iron bioavailability resulting in the higher anemia events. In the present study, low abortion history was found that might be because the study site was urban area with better health facilities. A survey conducted in Sub-Sahara Africa (Gebremedhin, 2019) showed exclusive breastfeeding and bottle feeding at first (12-15 months) and second year of 
Table 2. Demographics of volunteers.

\begin{tabular}{lcc}
\hline \multirow{2}{*}{\multicolumn{1}{c}{ Demographics }} & \multicolumn{2}{c}{$\begin{array}{c}\text { Lactating Women } \\
\text { (n }=184)\end{array}$} \\
\cline { 2 - 3 } & $f$ & $\%$ \\
\hline In the family marriage & 135 & 73.37 \\
Out of the family marriage & 049 & 26.63 \\
Abortion & 004 & 02.17 \\
Never Abortion & 180 & 97.83 \\
Premature Birth & 004 & 02.17 \\
Never Premature Birth & 180 & 97.83 \\
Family system (Joint) & 177 & 96.20 \\
Family system (Nuclear) & 007 & 03.80 \\
Breastfeeding (Less than 1 year) & 78 & 42.39 \\
Breastfeeding (Less than 2 years) & 51 & 27.72 \\
Breast plus Bottle feeding (Less than 1 year) & 18 & 09.78 \\
Breast plus Bottle feeding (Less than 2 years) & 13 & 07.07 \\
Bottle Feeding (Less than 1 year) & 17 & 09.24 \\
Bottle Feeding (Less than 2 years) & 7 & 03.80 \\
Family income (Less than Rs.20000) & 170 & 92.39 \\
Family income (Rs. 21000-39000) & 014 & 07.61 \\
Physical activity level (Sedentary) & 166 & 90.22 \\
Physical activity level (Slightly Active) & 018 & 09.78 \\
\hline
\end{tabular}

$\mathrm{n}=$ total no. of volunteers; $f=$ frequency.

study in the participants as $89,16.6,53$ and $11.7 \%$, respectively. In the study of Africa, percentage of breastfed and bottle-fed babies was comparable to results of our study.

\subsection{Anthropometric measurements}

After intervention of 90 days, all the treatment groups regarding anthropometrics showed non significant variations as shown in Table 3. Eighty two lactating anemic women of the age group $26.7 \pm 6.5$ years took either Moringa powder or Ferrous Sulphate (Idohou-Dossou et al., 2011). A non significant variation in weight $(58.9-58.1 \mathrm{Kg})$ and body mass index $\left(23.2\right.$ to $23.0 \mathrm{Kg} / \mathrm{m}^{2}$ ) of Moringa supplemented group was noted that is in accordance to present study. A randomized controlled clinical experiment was carried out to gauge the effect of dietary supplement on anthropometric measurements in lactating mothers (Kindra et al., 2011). It was explored that the dietary supplement had no significant effect on anthropometrics of breastfeeding mothers. In a study, reproductive age women (15-49 years) daily received $1.9 \mathrm{~kg}$ supplement of Hibiscus feast containing $1.71 \mathrm{mg}$ iron / $100 \mathrm{~g}$ feast (Kubuga et al., 2019). No significant variations were recorded in anthropometric measurements of volunteers that verify the findings of current study. Some authors (Kundu et al., 2013) investigated that BSA of mild anemic and moderate anemic women was $1.32 \pm 0.09$ and $1.25 \pm 0.05 \mathrm{~m}^{2}$. respectively. Optimum value of BSA in females is $1.8 \mathrm{~m}^{2}$ that also supports the findings of the current research study in which BSA after 90 days of intervention was $1.52 \pm 0.007 \mathrm{~m}^{2}$.

\subsection{Assessment of dietary intakes}

A significant positive impact of study was observed among all treatment groups regarding dietary intakes that might be due to nutrition education and dietary counseling (Table 4).
Table 3. Anthropometrics (mean values) of volunteers.

\begin{tabular}{lrrrrr}
\hline \multirow{2}{*}{ Variables } & \multicolumn{3}{c}{ Lactating $(\mathrm{n}=184)$} \\
\cline { 2 - 3 } \cline { 5 - 6 } \cline { 5 - 6 } & \multicolumn{2}{c}{ Day 0 } & & \multicolumn{2}{c}{ Day 90 } \\
\cline { 2 - 3 } \cline { 5 - 6 } Weight $(\mathrm{Kg})$ & $57.67^{\mathrm{A}}$ & 0.803 & & $57.23^{\mathrm{A}}$ & 0.770 \\
Height $(\mathrm{cm})$ & $155.02^{\mathrm{A}}$ & 0.379 & & $154.82^{\mathrm{A}}$ & 0.399 \\
Body mass index $\left(\mathrm{Kg} / \mathrm{m}^{2}\right)$ & $22.95^{\mathrm{A}}$ & 0.169 & & $22.96^{\mathrm{A}}$ & 0.169 \\
Body surface area $\left(\mathrm{m}^{2}\right)$ & $1.52^{\mathrm{A}}$ & 0.006 & & $1.52^{\mathrm{A}}$ & 0.007 \\
\hline n= total no. of volunteers. Data is expressed as mean values (SEM). SEM= standard \\
error of mean.
\end{tabular}

Table 4. Intake of water and no. of servings (mean values) of volunteers.

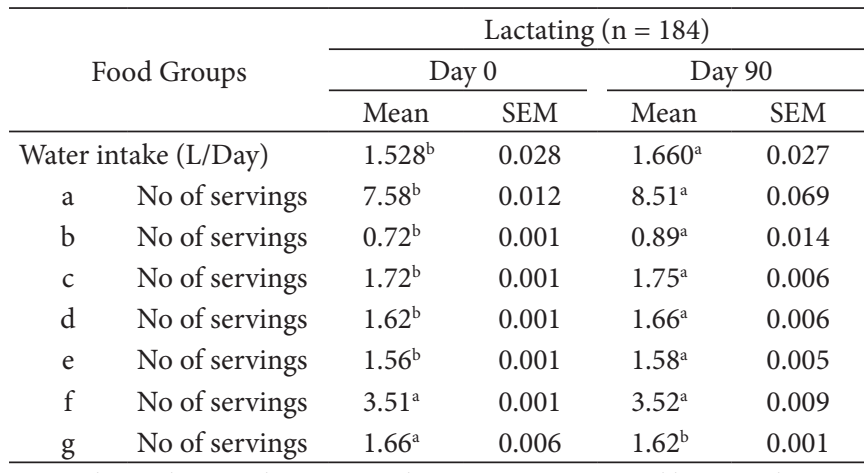

$\mathrm{a}=$ Bread, Cereal, Rice and Pasta Group; $\mathrm{b}=$ Fruit Group; $\mathrm{c}=$ Vegetable Group; $\mathrm{d}=$ Meat, Fish, Poultry, Beans, Eggs and Nuts Group; e= Milk, Yogurt and Cheese Group; f= Fats, Oils and Sweets Group; $\mathrm{g}=$ Junk Food Group. Data is expressed as mean values (SEM). $\mathrm{SEM}=$ standard error of mean. $\mathrm{P}$ value of all food groups is $<0.05$ at 90 days of study; $\mathrm{n}=$ total no. of volunteers.

Intake of most food group servings of all volunteers in present study was less compared to the Food Guide Pyramid recommended servings per day irrespective of the Bread, Cereal, Rice and Pasta Group. A study was conducted on 4,290 women of childbearing age (15 - 49 years) in Ghana (Ghose \& Yaya, 2018) so as to assess the prevalence of anemia and its relationship with fruits and vegetable consumption. Women which were not following the WHO recommendations for optimum fruits and vegetable servings, had more incidence of severe anemia that corroborates the results of present study. In pregnant and lactating women from rural area of Niger, assessment of food intakes was done by 24 hours dietary recall method (Wessells et al., 2019). Statistical analysis revealed that daily intake of one additional food serving along with leafy vegetables, vitamin A, yoghurt, pearl millet and beans will minimize the chances of inadequate dietary intakes in the study groups. A trial was conducted to assess food intake and micronutrients status of lactating women in Zambia by estimated average requirement. Half of the women were anemic (50\%) and majority of the women $(99.9 \%)$ had inadequate intakes of all micronutrients assessed by their low dietary diversity score (Kaliwile et al., 2019) which is in agreement to the findings of current study. Nutritional status of Ethiopian lactating mothers using dietary diversity score showed that dietary intakes of only $31.9 \%$ participants contained six food groups while 43.6 and $24.4 \%$ of volunteers ingested five and less than four food groups, respectively (Egata, 2018). Food abundantly consumed was cereal (94.8\%) accompanied by pulses and vegetables. Participants who consumed less than 
six food groups were more likely to be anemic that is more alike to the current study.

\subsection{Biochemical investigations}

Treatments, study interval and their interaction depicted a highly significant effect on all biochemical indices of lactating anemia that is evident from Table 5 and Figure 2A-D. Biochemical investigations of lactating volunteers were improved significantly by treatment $\mathrm{T}_{2}$ in 90 days which is proved by following results; TRBC (6.24\%), Hb (32.72\%), Hct (9.91\%), MCV (3.04\%), MCH (5.48\%), MCHC (4.86\%), s. Fe (12.57\%), s. ferritin $(35.72 \%)$, TS (50.64\%) and TIBC (5.19\%), respectively. Fe supplements commonly used to control IDA are Ferrous sulphate and Ferrous gluconate. But intake of these supplements is also accountable for various complications like depressed growth, abdominal discomfort and nausea. Molasses derived from sugarcane besides raising the iron status of deficient population also act as antioxidant (Asikin et al., 2013). An author reported (Tandon, 2002) that usually allopathic medicines are used to cure various illness and nutritional diseases while natural food sources are ignored. Hence a shift from pill to natural food sources is a hard task but emphasis should be prioritized to convince the public to take up the natural common food simply as the best remedy for the control of IDA.

On hundred ninety three $(n=193)$ females (Mozaffari-Khosravi et al., 2010) were randomly divided in to iron supplemented or un-supplemented group. Iron supplemented group (ISG) used weekly $150 \mathrm{mg}$ Ferrous sulphate for 4 months while un-supplemented group (IUG) took placebo. The study revealed that this low dose iron effectively improved iron status and there is no need for higher doses of iron that is in close agreement to our study. In a study, rats fed on diet of soybean, pulses, sesame seeds, pumpkin seeds, blackstrap molasses and their mix as iron source, had significant rise in anemia indices such as Hb, Hct, MCV, MCH and MCHC (Yun et al., 2011). A research worker (Jain, 2013) formulated biscuits, handwa, idli and soy chat following food fortification strategy. Group one of twice weekly medicinal iron had significant rise in $\mathrm{Hb}$ concentration $(\mathrm{p}<0.05)$. Similarly, food iron supplement was also effective in improving the anemia indices $(\mathrm{p}<0.05)$ which maintained the $\mathrm{Hb}$ levels of volunteers for 120 days while medicinal iron did not behave so. Hence food based strategy

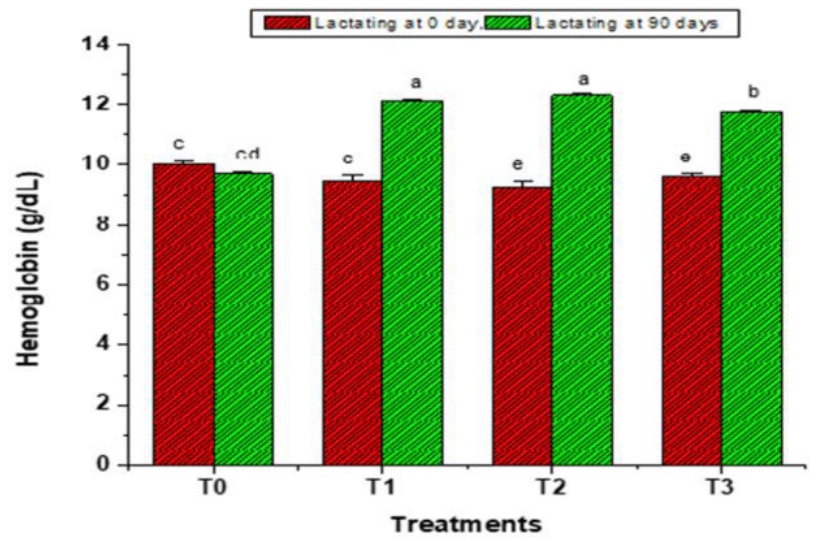

A

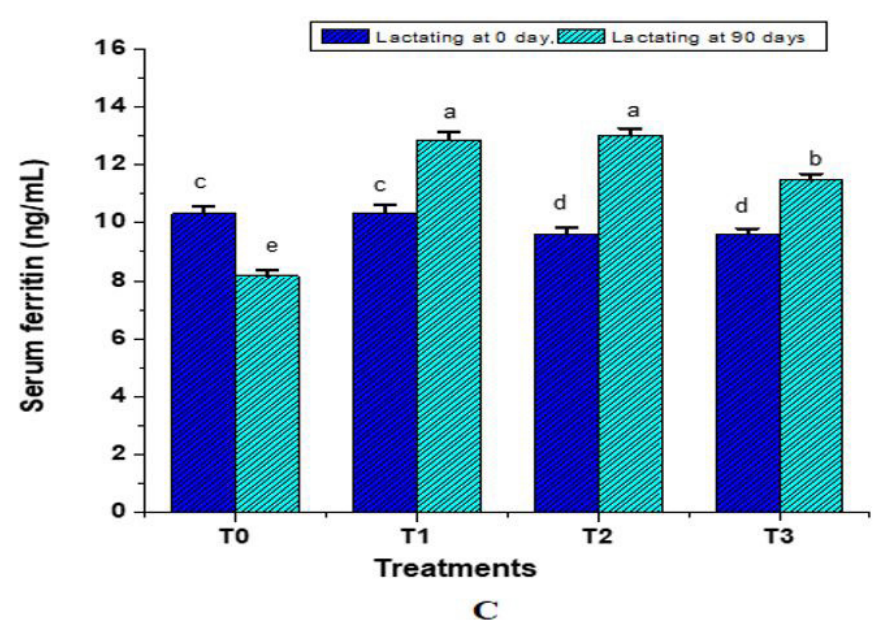

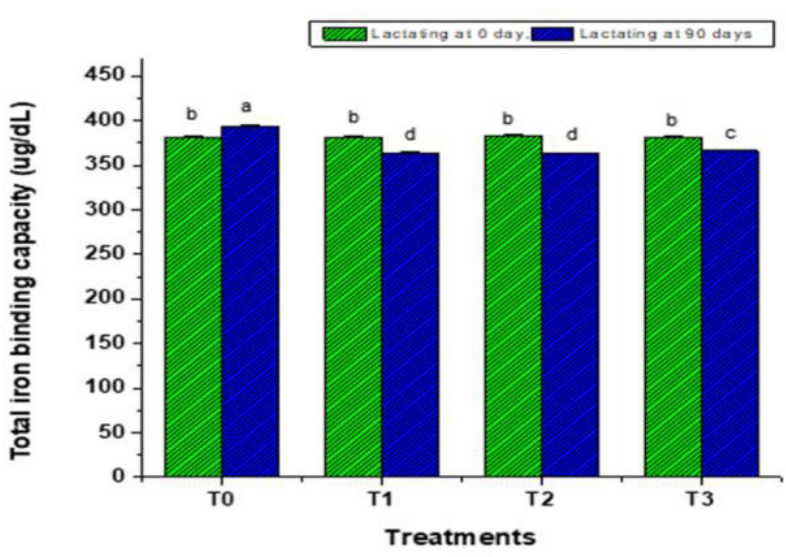

B

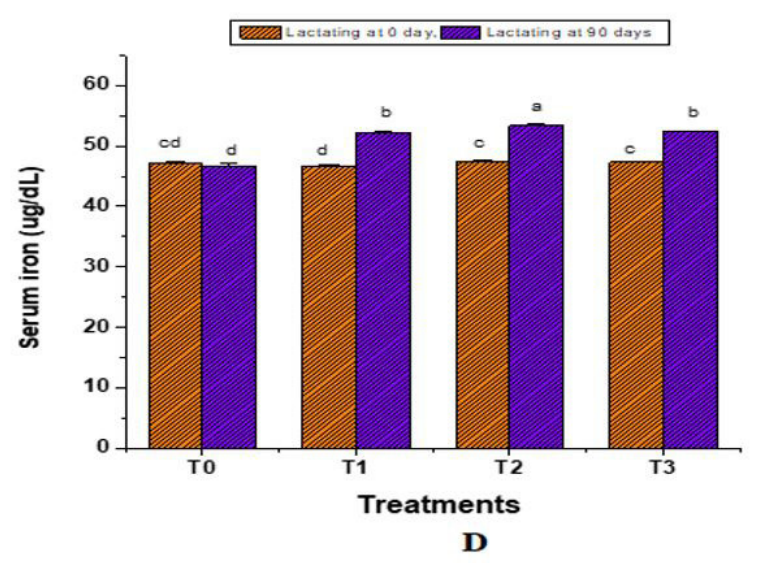

Figure 2. Column graphs showing mean variation in hematological variables of hemoglobin (2A) total iron binding capacity (2B) serum ferritin (2C) and serum iron (2D) of lactating women at baseline ( 0 day) and after the end of intervention ( 90 days) by intake of various treatments of iron such as $\mathrm{T}_{0}$ (control), $\mathrm{T}_{1}, \mathrm{~T}_{2}$ and $\mathrm{T}_{3}$. All treatments had $\mathrm{P}<0.05$ at post intervention phase. P-value is from paired $\mathrm{t}$-test. 
Table 5. Biochemical indices of IDA of Lactating volunteers.

\begin{tabular}{|c|c|c|c|c|c|c|}
\hline \multirow{3}{*}{ Biomarkers of Volunteers $(\mathrm{n}=184)$} & \multirow{3}{*}{ Treatments } & \multicolumn{4}{|c|}{ Days } & \multirow{3}{*}{ P value } \\
\hline & & \multicolumn{2}{|c|}{0} & \multicolumn{2}{|c|}{90} & \\
\hline & & Mean & SEM & Mean & SEM & \\
\hline \multirow[t]{4}{*}{ Total red blood cells $(\mathrm{M} / \mathrm{uL})$} & $\mathrm{T}_{0}$ & $4.56^{c}$ & 0.009 & $4.46 f$ & 0.008 & 0.005 \\
\hline & $\mathrm{T}_{1}$ & $4.59^{\mathrm{e}}$ & 0.010 & $4.79^{c}$ & 0.011 & 0.004 \\
\hline & $\mathrm{T}_{2}$ & $4.65^{\mathrm{d}}$ & 0.013 & $4.94^{\mathrm{a}}$ & 0.014 & 0.001 \\
\hline & $\mathrm{T}_{3}$ & $4.66^{\mathrm{d}}$ & 0.013 & $4.86^{\mathrm{b}}$ & 0.014 & 0.005 \\
\hline \multirow[t]{4}{*}{ Hemoglobin $(\mathrm{g} / \mathrm{dL})$} & $\mathrm{T}_{0}$ & $10.03^{c}$ & 0.111 & $9.70^{\mathrm{cd}}$ & 0.097 & 0.004 \\
\hline & $\mathrm{T}_{1}$ & $9.47^{\mathrm{de}}$ & 0.200 & $12.11^{\mathrm{a}}$ & 0.076 & 0.002 \\
\hline & $\mathrm{T}_{2}$ & $9.29^{e}$ & 0.158 & $12.33^{\mathrm{a}}$ & 0.069 & 0.001 \\
\hline & $\mathrm{T}_{3}$ & $9.60^{\mathrm{de}}$ & 0.132 & $11.76^{\mathrm{b}}$ & 0.057 & 0.005 \\
\hline \multirow[t]{4}{*}{ Mean corpuscular volume (fL) } & $\mathrm{T}_{0}$ & $75.97^{\mathrm{c}}$ & 0.084 & $74.51^{\mathrm{d}}$ & 0.086 & 0.007 \\
\hline & $\mathrm{T}_{1}$ & $75.97^{\mathrm{c}}$ & 0.080 & $78.00^{\mathrm{a}}$ & 0.080 & 0.006 \\
\hline & $\mathrm{T}_{2}$ & $76.05^{c}$ & 0.101 & $78.36^{\mathrm{a}}$ & 0.098 & 0.002 \\
\hline & $\mathrm{T}_{3}$ & $75.90^{c}$ & 0.104 & $77.91^{\mathrm{b}}$ & 0.105 & 0.007 \\
\hline \multirow[t]{4}{*}{ Serum iron (ug/dL) } & $\mathrm{T}_{0}$ & $47.26^{\mathrm{cd}}$ & 0.161 & $46.74^{\mathrm{d}}$ & 0.326 & 0.005 \\
\hline & $\mathrm{T}_{1}$ & $46.71^{\mathrm{d}}$ & 0.211 & $52.23^{\mathrm{b}}$ & 0.156 & 0.004 \\
\hline & $\mathrm{T}_{2}$ & $47.40^{c}$ & 0.285 & $53.36^{\mathrm{a}}$ & 0.254 & 0.003 \\
\hline & $\mathrm{T}_{3}$ & $47.37^{\mathrm{c}}$ & 0.118 & $52.49^{\mathrm{b}}$ & 0.071 & 0.006 \\
\hline \multirow[t]{4}{*}{ Serum total iron binding capacity (ug/dL) } & $\mathrm{T}_{0}$ & $381.56^{\mathrm{b}}$ & 1.041 & $394.29^{\mathrm{a}}$ & 0.662 & 0.006 \\
\hline & $\mathrm{T}_{1}$ & $382.04^{\mathrm{b}}$ & 0.831 & $364.06^{\mathrm{d}}$ & 0.710 & 0.005 \\
\hline & $\mathrm{T}_{2}$ & $383.30^{\mathrm{b}}$ & 0.682 & $363.39^{d}$ & 0.692 & 0.001 \\
\hline & $\mathrm{T}_{3}$ & $381.85^{\mathrm{b}}$ & 0.645 & $366.63^{\mathrm{c}}$ & 1.114 & 0.003 \\
\hline \multirow[t]{4}{*}{ Serum ferritin (ng/mL) } & $\mathrm{T}_{0}$ & $10.32^{\mathrm{c}}$ & 0.249 & $8.16^{\mathrm{e}}$ & 0.231 & 0.004 \\
\hline & $\mathrm{T}_{1}$ & $10.35^{\mathrm{c}}$ & 0.287 & $12.85^{\mathrm{a}}$ & 0.275 & 0.001 \\
\hline & $\mathrm{T}_{2}$ & $9.60^{\mathrm{d}}$ & 0.252 & $13.03^{\mathrm{a}}$ & 0.238 & 0.000 \\
\hline & $\mathrm{T}_{3}$ & $9.62^{\mathrm{d}}$ & 0.187 & $11.48^{\mathrm{b}}$ & 0.210 & 0.002 \\
\hline \multirow[t]{4}{*}{ Serum transferrin saturation (\%) } & $\mathrm{T}_{0}$ & $12.92^{\mathrm{d}}$ & 0.172 & $9.91^{\mathrm{e}}$ & 0.168 & 0.004 \\
\hline & $\mathrm{T}_{1}$ & $13.07^{\mathrm{d}}$ & 0.164 & $19.15^{\mathrm{b}}$ & 0.155 & 0.003 \\
\hline & $\mathrm{T}_{2}$ & $13.23^{\mathrm{d}}$ & 0.173 & $19.93^{\mathrm{a}}$ & 0.153 & 0.001 \\
\hline & $\mathrm{T}_{3}$ & $13.36^{\mathrm{d}}$ & 0.166 & $18.14^{\mathrm{c}}$ & 0.170 & 0.003 \\
\hline
\end{tabular}

Day $90=$ after intervention of 90 days (Post intervention). Day $0=$ at baseline before intervention (Pre intervention); $\mathrm{n}=$ total no. of volunteers, SEM= standard error of mean; $\mathrm{p}$ value is from Paired t-test.

for controlling anemia has more potential for $\mathrm{Hb}$ sustainability. In another study, 150 non lactating anemic females were given daily $100 \mathrm{~g}$ iron fortified soy flour cookies up to four months. Therapeutic effects of the fortified cookies showed a positive significant increase in $\mathrm{Hb}$, serum iron and white blood cells count (Sari et al., 2018). Food based approaches on community levels in terms of iron fortification for the control of IDA are (Akhter et al., 2014) becoming more popular. In this regard, fresh buffalo milk was fortified with Ferrous sulphate and fed to Sprague Dawley rats to evaluate its impact on IDA. After the intervention for 8 weeks, $\mathrm{Hb}(\mathrm{g} / \mathrm{dL})$ of experimental groups depicted significant increase $(9.84 \pm 0.287$ to $14.37 \pm 0.325)$ in comparison to the placebo group $(\mathrm{p} \leq 0.05)$. In a study, 195 women (18-27 years) were fed with iron fortified beans ( $86 \mathrm{mg}$ iron per $\mathrm{kg}$ ) and normal beans for an interval of four months in Rwanda (Haas et al., 2016). At the end of study, iron fortified beans (food sources of iron containing supplement) depicted significant and greater rise in $\mathrm{Hb}(3.8 \mathrm{~g} / \mathrm{l})$, ferritin $(0.1 \mathrm{mg} / \mathrm{l})$ and serum iron $(0.5 \mathrm{mg} / \mathrm{Kg})$ than control group $(\mathrm{P}<0.05)$.

Efficacy study of a composite product of amla, jaggery and pumpkin foliage was carried out in iron deficiency anemic female youngsters (Resmi et al., 2017). At the competition of study, $\mathrm{Hb}$ and serum iron of participants showed positive improvement of 9.94 to $10.99 \mathrm{~g} / \mathrm{dl}$ and 77.6 to $99.58 \mathrm{ug} / \mathrm{dl}$, respectively. Another similar study was done on 170 female youngsters (Bhuvaneswari et al., 2017) in order to gauge the usefulness of iron- folic acid and a mixture of honey, dates and amla (local common natural food items). After the study, food mixture group showed significant improvement in anemia indices in comparison to the iron group. The author had view that people should be convinced to consume local food items that has beneficial therapeutic efficacy in order to fulfill nutritional deficiencies. Fifty $(n=50)$ medical college students were randomly allocated to receive a dietary supplement; $5 \mathrm{~g}$ each of Jaggery ball and raisins (Sakthibalan et al., 2018). Food supplement was provided daily up to two months. At the end of intervention, a significant increase in $\mathrm{Hb}$ and total $\mathrm{RBC}$ count of female volunteers was recorded without any adverse reaction as often reported in various intravenous and oral administrations. Hence it may be used as preventive strategy to combat IDA in susceptible inhabitants that is in accordance to current study upshot. Iron supplement was provided to 68 anemic young girls (Sari et al., 2018). It was revealed after the study that combined 
therapy of iron supplement and dates showed more significant difference in iron status of adolescents than the control one. In a study, reproductive age women (15-49 years) were daily fed with supplement of Hibiscus feast (Kubuga et al., 2019). Iron status of anemic volunteers showed significant positive effects that also verify the findings of current study.

\section{Conclusions}

To the best of our knowledge no such study on lactating women has been conducted in Pakistan from the last two decades where majority of people are poor and are not able to adequately feed their family. Due to this reason, not only the health of lactating mother is badly affected but their young ones are malnourished too. Resultantly, maternal and child mortality rate is high in the country. In this study, treatments of synthetic and food sources of iron equally provided $50 \% \mathrm{RDA}$ of $\mathrm{Fe}$ ( $4.5 \mathrm{mg}$ ) among various lactating groups with the exception of placebo $\left(\mathrm{T}_{0}\right)$. Anthropometrics and energetics of lactating women showed non significant variations while dietary intakes of all groups depicted significant effect of the study interval. Response of biochemical investigations of volunteers by treatment $T_{2}$ was significantly better and more persistent as compared to all other treatments. Safety of the dietary interventions was confirmed by linear variations recorded during LFTs and RFTs. It may be concluded from the study findings that food sources of iron such as blackstrap molasses have more bioavailable iron in comparison to synthetic source and may be effectively used in anemic lactating volunteers which is an overlooked important segment of the Pakistani population.

\section{Acknowledgements}

The authors are thankful to the Department of Population Welfare, Faisalabad, Government of Punjab, Pakistan, for permission to conduct the study and assistance in the arrangement of volunteers.

\section{References}

Akhter, N., Iqbal, S., Nasir, M., Ashraf, A., Bacha, U., \& Khan, M. A. (2014). Iron fortified pasteurized milk: Physico-chemical attributes and efficacy against iron deficiency anaemia in sprague dawley rats. Journal of Animal and Plant Sciences, 24(4), 1062-1068.

Anand, R., Mishra, A. K., Mahdi, A. A., Verma, S. P., \& Gupta, K. K. (2018). A study of prevalence and pattern of anemia in primary hypothyroidism. International Journal of Medical Science and Public Health, 7(2), 153-160. http://dx.doi.org/10.5455/ijmsph.2018.1131728122017.

Asikin, Y., Takahashi, M., Mishima, T., Mizu, M., Takara, K., \& Wada, K. (2013). Antioxidant activity of sugarcane molasses against 2, 2 '-azobis (2-amidinopropane) dihydrochloride-induced peroxyl radicals. Food Chemistry, 141(1), 466-472. http://dx.doi.org/10.1016/j. foodchem.2013.03.045. PMid:23768381.

Bhuvaneswari, G., Kerubhaman, H., \& Mangala, C. P. (2017). Effects of iron and folic acid v's honey dates amla mix on increasing haemoglobin level among adolescent girls. International Journal of Development Research, 7(9), 15007-15011.

Cepeda-Lopez, A. C., Melse-Boonstra, A., Zimmermann, M. B., \& Herter-Aeberli, I. (2015). In overweight and obese women, dietary iron absorption is reduced and the enhancement of iron absorption by ascorbic acid is one-half that in normal-weight women. The American Journal of Clinical Nutrition, 102(6), 1389-1397. http:// dx.doi.org/10.3945/ajcn.114.099218. PMid:26561622.

Egata, G. (2018). Undernutrition and Its Associated Factors among lactating women in Gog District, Angwa Zone, Gambella Region, South West Ethiopia. (Ph D Thesis). Ethiopia: Haramaya University.

Gebremedhin, S. (2019). Core and optional infant and young child feeding indicators in Sub Saharan Africa: A cross-sectional study. BMJ Open, 9(2), 023238. http://dx.doi.org/10.1136/bmjopen-2018-023238. PMid:30782876.

Ghose, B., \& Yaya, S. (2018). Fruit and vegetable consumption and anemia among adult non-pregnant women: Ghana Demographic and Health Survey. PeerJ, 6, e4414. http://dx.doi.org/10.7717/ peerj.4414. PMid:29492346.

Haas, J. D., Luna, S. V., Lungaho, M. G., Wenger, M. J., Murray-Kolb, L. E., Beebe, S., Gahutu, J. B., \& Egli, I. M. (2016). Consuming iron biofortified beans increases iron status in Rwandan women after 128 days in a randomized controlled feeding trial. The Journal of Nutrition, 146(8), 1586-1592. http://dx.doi.org/10.3945/jn.115.224741. PMid:27358417.

Herranz-Lopez, M., Olivares-Vicente, M., Boix-Castejon, M., Caturla, N., Roche, E., \& Micol, V. (2019). Differential effects of a combination of Hibiscus sabdariffa and Lippia citriodora polyphenols in overweight/ obese subjects:A randomized controlled trial. Scientific Reports, 9(1), 2999-2999. http://dx.doi.org/10.1038/s41598-019-39159-5. PMid:30816148.

Idohou-Dossou, N., Diouf, A., Gueye, A. L., Guiro, A. T., \& Wade, S. (2011). Impact of daily consumption of Moringa (Moringa oleifera) dry leaf powder on iron status of Senegalese lactating women. African Journal of Food, Agriculture, Nutrition and Development, 11(4), 4985-4999. http://dx.doi.org/10.4314/ajfand.v11i4.69176.

Inobaya, M. T., Chau, T. N., Ng, S.-K., MacDougall, C., Olveda, R. M., Tallo, V. L., Landicho, J. M., Malacad, C. M., Aligato, M. F., Guevarra, J. B., \& Ross, A. G. (2018). Mass drug administration and the sustainable control of schistosomiasis: an evaluation of treatment compliance in the rural Philippines. Parasites \& Vectors, 11(1), 1-11. http://dx.doi.org/10.1186/s13071-018-3022-2. PMid:30064469.

Jain, M. (2013). Combating iron deficiency anaemia through food-tofood fortification: recipe development, iron bioavailability and effect of supplementation. International Journal of Food and Nutritional Sciences, 2(1), 93-101.

Jain, R., \& Venkatasubramanian, P. (2017). Sugarcane Molasses-A Potential Dietary Supplement in the Management of Iron Deficiency Anemia. Journal of Dietary Supplement, 14,(5) 589-598. http://dx.doi. org/10.1080/19390211.2016.1269145. PMid:28125303.

Kaliwile, C., Michelo, C., Titcomb, T. J., Moursi, M., Angel, M. D., \& Reinberg, C. (2019). Dietary Intake Patterns among Lactating and Non-Lactating Women of Reproductive Age in Rural Zambia. Nutrients, 11(2), 1-15. http://dx.doi.org/10.3390/nu11020288. PMid:30699920.

Kassebaum, N. J., Jasrasaria, R., Naghavi, M., Wulf, S. K., Johns, N., Lozano, R., Regan, M., Weatherall, D., Chou, D. P., Eisele, T. P., Flaxman, S. R., Pullan, R. L., Brooker, S. J., \& Murray, C. J. (2010). A systematic analysis of global anemia burden from 1990 to 2010. Blood, 123(5), 615-624. http://dx.doi.org/10.1182/blood-2013-06-508325. PMid:24297872.

Kindra, G., Coutsoudis, A., \& Esposito, F. (2011). Effect of nutritional supplementation of breastfeeding HIV positive mothers on maternal and child health: Findings from a randomized controlled clinical trial. BMC Public Health, 11(1), 946. http://dx.doi.org/10.1186/14712458-11-946. PMid:22192583. 
Kubuga, C. K., Hong, H. G., \& Song, W. O. (2019). Hibiscus sabdariffa meal improves iron status of childbearing age women and prevents stunting in their Toddlers in Northern Ghana. Nutrients, 11(1), 1-12. http://dx.doi.org/10.3390/nu11010198. PMid:30669431.

Kundu, S., Prasad, S. K., Maji, B., Ray, D., Syamal, A. K., \& Mukherjee, S. (2013). Nutritional status and productivity of female tea pluckers of a tea garden in Dooars, West Bengal. International Journal of Biological and Medical Research, 4, 3101-3106.

Manavifar, L., Keramati, M. R., Jamali, J., Tavakkoli, S., Mansouritorghabeh, H., \& Hashemy, S. I. (2014). The Association between Neutrophilic Hypersegmentation and iron deficiency with regard to folate status in 16-30 Year-Old Women. Clinical Laboratory, 60(3), 517-522. http://dx.doi.org/10.7754/Clin.Lab.2013.130146. PMid:24697133.

Mhanna, R. G., Rahal, M., Iskandarani, M., \& Hammoudi, D. (2016). Incidence and risk factors associated with iron deficiency anaemia among hospitalised L ebanese infants. International Journal of Pharmacy Practice, 24(3), 203-208. http://dx.doi.org/10.1111/ ijpp.12236. PMid:26671320.

Milman, N. (2011). Anemia-still a major health problem in many parts of the world. Annals of Hematology, 90(4), 369-377. http://dx.doi. org/10.1007/s00277-010-1144-5. PMid:21221586.

Mozaffari-Khosravi, H., Noori-Shadkam, M., Fatehi, F., \& Naghiaee, Y. (2010). Once weekly low-dose iron supplementation effectively improved iron status in adolescent girls. Biological Trace Element Research, 135(1-3), 22-30. http://dx.doi.org/10.1007/s12011-0098480-0. PMid:19652922.

Nath, D. C. (2015). Two stage sampling design for estimation of total fertility rate: with an illustration for slum dweller married women. Electronic Journal of Applied Statistical Analysis, 8, 112-121.

Resmi, S., Latheef, F., \& Vijayaraghavan. (2017). Effectiveness of amla, jaggery and pumpkin leaves extract on the level of haemoglobin, vitamin $\mathrm{c}$ and iron among adolescent girls with iron deficiency anemia. International Journal of Pharmaceutical Sciences and Research, 8(11), 4812-4817.

Sakthibalan, M., Sarumathi, E., Mangaiarkkarasi, A., \& Meher, B. R. (2018). Evaluation of efficacy of jaggery and raisins as supplements in iron deficiency anemia among medical undergraduate students in South India. National Journal of Physiology, Pharmacy and Pharmacology, 8(10), 1432-1436.

Sari, A., Pamungkasari, E. P., \& Dewi, Y. L. R. (2018). The addition of dates palm (Phoenix dactylifera) on iron supplementation $(\mathrm{Fe})$ increases the hemoglobin level of adolescent girls with anemia. Bali Medical Journal, 7(2), 356-360. http://dx.doi.org/10.15562/ bmj.v7i2.987.

Saryono, M., \& Rahmawati, E. (2016). Effects of dates fruit (Phoenix dactylifera L.) in the female reproductive process. International Journal of Recent Advances in Multidisciplinary Research, 3, 1630-1633.
Sathyamala, C. (2017). Global Nutrition Report 2016: from promise to impact: ending malnutrition by 2030. Washington, DC: International Food Policy Research Institute.

Sharami, S. H., Milani, F., Mohamadi, F., Pourmarzi, D., Kazemnejad, E., \& Mollaee, R. (2017). Anthropometric, clinical and biochemical comparison of the four polycystic ovarian syndrome phenotypes. The Kuwait Medical Journal: KMJ : the Official Journal of the Kuwait Medical Association, 49(3), 216-222.

Siddiqui, M. Z., Goli, S., Reja, T., Doshi, R., Chakravorty, S., Tiwari, C., Kumar, N. P., \& Singh, D. (2017). Prevalence of anemia and its determinants among pregnant, lactating, and nonpregnant nonlactating women in India. SAGE Open, 7(3), 1-10. http://dx.doi. org/10.1177/2158244017725555.

Spieth, P. M., Kubasch, A. S., Penzlin, A. I., Illigens, B. M.-W., Barlinn, K., \& Siepmann, T. (2016). Randomized controlled trials - a matter of design. Neuropsychiatric Disease and Treatment, 12, 1341-1349. PMid:27354804.

Tandon, B. (2002). Indo-US workshop and health of women, infants, and children-National Institute of Nutrition, Hyderabad, February 10-12, 2000. Nutrition Reviews, 60(5): S1.

US Department of Agriculture. Agricultural Research Service. (2018). Branded Food Products Database. USDA Branded Food Products Database Release July 2018. Beltsvile, MD: United States Department of Agriculture.

Wessells, K., Young, R., Ferguson, E., Ouédraogo, C. T., Faye, M. T., \& Hess, S. Y. (2019). Assessment of dietary intake and nutrient gaps, and development of food-based recommendations, among pregnant and lactating women in Zinder, Niger: An optifood linear programming analysis. Nutrients, 11(1), 1-23. http://dx.doi. org/10.3390/nu11010072. PMid:30609695.

Wessling-Resnick, M. (2017). Excess iron: Considerations related to development and early growth. The American Journal of Clinical Nutrition, 106(Suppl 6), 1600S-1605S. http://dx.doi.org/10.3945/ ajcn.117.155879. PMid:29070548.

Yilmaz, I., Temel, I., Gursoy, S., Dogan, Z., \& Turkoz, Y. (2012). Effects of sun dried organic apricot on some serum mineral levels in rats. International Research Journal of Pharmaceuticals, 2, 62-67.

Yun, S., Zhang, T., Li, M., Chen, B., \& Zhao, G. (2011). Proanthocyanidins inhibit iron absorption from soybean (Glycine max) seed ferritin in rats with iron deficiency anemia. Plant Foods for Human Nutrition, 66(3), 212-217. http://dx.doi.org/10.1007/s11130-011-0240-6. PMid:21720790.

Zoccatelli, D., Tramer, M. R., \& Elia, N. (2018). Identification of ethics committees based on authors' disclosures: cross-sectional study of articles published in the European Journal of Anaesthesiology and a survey of ethics committees. BMC Medical Ethics, 19(1), 57. http:// dx.doi.org/10.1186/s12910-018-0289-y. PMid:29884170. 